\title{
DIAMETER STRUCTURE IN A COMMUNITY OF SHRUB-TREE CAATINGA, MUNICIPALITY OF FLORESTA, STATE OF PERNAMBUCO, BRAZIL
}

\author{
Robson Borges de Lima ${ }^{1 *}$, Rinaldo Luiz Caraciolo Ferreira ${ }^{2}$, José Antônio Aleixo da Silva², Francisco Tarcísio \\ Alves Júnior ${ }^{1}$, Cinthia Pereira de Oliveira ${ }^{2}$, Gilson Fernandes da Silva ${ }^{3}$ \\ ${ }^{1}$ University of Amapá, College of Forestry, Macapá, Amapá, Brazil - robson.lima@ueap.edu.br, francisco.junior@ueap.edu.br \\ ${ }^{2}$ Federal University of Pernambuco, Department of Forest Science, Recife, Pernambuco, Brazil - rinaldodcfl@ gmail.com, \\ jaaleixo@uol.com.br, cinthia.florestal@gmail.com \\ ${ }^{3}$ Federal University of Espírito Santo, Department of Forest and Wood Science, Jerônimo Monteiro, Espírito Santo, Brazil - \\ gilson.silva@pq.cnpq.br
}

Received for publication: 22/08/2017 - Accepted for publication: 16/11/2017

\begin{abstract}
This study aimed to analyze the diameter structure of the stand and of five species of highest importance value (IV) for a Caatinga area located in the municipality of Floresta, state of Pernambuco, Brazil. 40 sample units of $400 \mathrm{~m}^{2}$ each, systematically allocated, were used. All shrub-tree individuals with base circumference $(0.30 \mathrm{~m})$ greater than or equal to $6 \mathrm{~cm}$ were measured. De Liocourt quotient q was used to verify discrepancies between recruitment and mortality rates. It was reported, for the studied area, the species Poincianella bracteosa (Tul.) L. P. Queiroz, Mimosa ophthalmocentra Mart. ex Benth., Aspidosperma pyrifolium Mart., Myracrodum urundeuva (Engl.) Fr. All. and Bauhinia cheilanta (Bong). Steud. represented 77.25\% of the total sampled density. Diameter distributions indicated that regeneration occurs continuously. Based on the quotient $q$, we can infer that individuals' mortality has been compensated by recruitment in different diameter classes for the studied stand, Myracrodum urundeuva, and Poincianellabracteosa. However, the diameter structure for Mimosa ophthalmocentra, Aspidosperma pyrifolium, and Bauhinia cheilanta indicated maintenance and development problems for these species.

Keywords: Dry tropical forest, forest Inventory, semiarid.
\end{abstract}

\section{Resumo}

Estrutura diamétrica em uma comunidade de caatinga arbustiva-arbórea, município de Floresta, Pernambuco. Este estudo teve como objetivo analisar a estrutura diamétrica do povoamento e de cinco espécies de maior valor de importância para uma área de Caatinga, localizada no município de Floresta, Pernambuco. Foram utilizadas 40 unidades amostrais de $400 \mathrm{~m}^{2}$ cada, alocadas sistematicamente. Foram mensurados todos os indivíduos arbustivo-arbóreos com circunferência na base $(0,30 \mathrm{~m})$ maior ou igual a $6 \mathrm{~cm}$. Foi empregado o quociente "q" de De Liocourt para verificar as discrepâncias entre as taxas de recrutamento e mortalidade. Reportou-se, para a área estudada, que as espécies Poincianella bracteosa(Tul.) L. P. Queiroz, Mimosa ophthalmocentra Mart. ex Benth., Aspidosperma pyrifolium Mart., Myracrodum urundeuva (Engl.) Fr. All. e Bauhinia cheilanta (Bong). Steud. representaram 77,25\% do total da densidade amostrada. As distribuições diamétricas indicaram que a regeneração ocorre continuamente. Por meio do quociente "q", pode-se inferir que, para o povoamento estudado, Myracrodum urundeuva e Poincianella bracteosa, a mortalidade de indivíduos está sendo recompensada pelo recrutamento nas diferentes classes de diâmetro. No entanto, a estrutura diamétrica para Mimosa ophthalmocentra, Aspidosperma pyrifolium e Bauhinia cheilanta indicou problemas de manutenção e desenvolvimento dessas espécies.

Palavras-chave: Floresta tropical seca, inventário florestal, semiárido.

\section{INTRODUCTION}

Among tropical and subtropical forest categories in the world, dry forests comprise less than half of them (POWERS et al., 2009). Despite their importance, they are among the most threatened and least studied forest ecosystems. As a result, they may be under higher risk than rainforests (PORTILLO-QUINTERO; SÁNCHEZAZOFEIFA, 2010; AIDE et al., 2012).

This type of forest presents different diameter distributions, both in its amplitude and form. Such information becomes important since it characterizes the forest dynamics and growing stock (RUBIN et al., 2006). The diameter distribution descriptive analysis by means of statistical models is a technique that implicitly predicts the current yield, as

FLORESTA, Curitiba, PR, v. 48, n. 1, p. 133-142, jan./mar. 2018.

Lima. R.B. et al.

ISSN eletrônico 1982-4688

DOI: $10.5380 /$ rf.v48 i1.54736 
it predicts the number of trees by means of the diameter class and height of each class (ROBINSON; HAMANN, 2011; BURKHART; TOMÉ, 2012). Thus, it provides more detailed information on the stand structure regarding recruitment and mortality rates (MARTÍNEZ-ANTÚNEZ et al., 2015).

Information on diameter structure and distribution are important tools to manage forest resources. Its interpretation contributes to silvicultural decisions, as well as to harvest decisions (ROBINSON; HAMANN, 2011). Diameter distributions are also used as inputs for growth models. Sometimes, they form the basis of the growth model itself. Consequently, information on the diameter distribution of a forest stand, as it is and how it might be in the future, is very useful for forest management. Burkhart and Tomé (2012) provide a useful overview of the uses and interpretation of diameters distribution in forest management.

In the São Francisco (PE) mesoregion, the municipality of Floresta stands out for concentrating expressively the vegetation of the Caatinga domain (EMBRAPA, 2001; SCIENTIFIC TECHNICAL COMMITTEE OF THE CAATINGA FOREST MANAGEMENT NETWORK, 2005). The Caatinga has been dedicated to the conservation and production of wood for energy purposes through management plans. In this sense, understanding the diameter structure may provide more evident answers regarding the development of the species (ALVES JUNIOR et al., 2013). Besides, it may allow inferences regarding the conservation level of forest communities and of species of greater occurrence in the area and in the process of understanding the ecological succession (MEYER, 1952).

Thus, the objective of this study was to analyze the diameter structure of the shrub-tree community and of the species of highest importance value (IV) for a Caatinga area located in the municipality of Floresta, state of Pernambuco, Brazil. We based our study on the hypothesis that the diameter structure of the analyzed cases shows signs that recruitment compensates the individuals' mortality.

\section{MATERIAL AND METHODS}

\section{Study location}

The study was carried out in the area of the Itapemirim Farm, which belongs to Agroindustrial Excelsior S.A., located in the municipality of Floresta, mesoregion of São Francisco (PE) ( $8^{\circ} 30^{\prime} 37^{\prime \prime} \mathrm{S}$ and $37^{\circ} 59^{\prime} 07^{\prime \prime} \mathrm{W}$ ). The vegetation is predominantly steppic-savanna-caatinga (dry tropical forest), characterized by shrub-tree vegetation, with cacti and herb layer (IBGE, 2012). The farm extension is approximately 6,000 ha.

The climate, according to Köppen classification, is BSh: hot semiarid, with an annual average rainfall of approximately 400 to $500 \mathrm{~mm}$, a rainy period from January to April, and an annual average temperature of $26.1^{\circ} \mathrm{C}$. The municipality has an area of 3,643.97 $\mathrm{km}^{2}$ and an average altitude of $323 \mathrm{~m}$ (EMBRAPA, 2001). The region's soil is classified as shallow chromic luvisol, sandy to medium and with a superficial surface texture. Gravelly soils, more fertile, predominate in the valleys' slopes (EMBRAPA, 2006).

\section{Data collection and analysis}

The forest inventory began in 2008, following the protocol of permanent plots measurements (SCIENTIFIC TECHNICAL COMMITTEE OF THE CAATINGA FOREST MANAGEMENT NETWORK, 2005). The area destined for the inventory has approximately 50 ha. The inventory corresponded to the allocation of 40 plots of $20 \times 20 \mathrm{~m}\left(400 \mathrm{~m}^{2}\right)$, where all shrub-tree individuals of circumference equal to or greater than $6 \mathrm{~cm}(\mathrm{Cb} \geq 6 \mathrm{~cm})$ were identified and measured for the circumference at stem base $(\mathrm{Cb}-0.30 \mathrm{~m}$ at the ground level). After they were converted to diameter at stem base $(\mathrm{Db} \mathrm{cm})$, individuals with more than one stem had their base diameters calculated by the equivalent diameter (BURKHART; TOMÉ, 2012).

Sample adequacy was analyzed to verify stability in the species-area curve, as described by Schilling et al. (2012). In this case, the sample adequacy calculation was performed to obtain the estimate of the optimal number of sample units that would be representative for the study (PÉLLICO NETO; BRENA, 1997). For all cases, a permissible error limit of $10 \%$, with $5 \%$ probability, was adopted. Thus, we considered the data for an infinite population according to expression 1 :

$$
n=\frac{t_{\alpha}^{2} S^{2}}{E^{2}+\frac{t_{\alpha}^{2} S^{2}}{N}}
$$

In which: $n=$ optimal number of sample units; $t^{2}=$ tabulated value of Student's $t$ test $(\alpha=0.05) ; S^{2}=$ sample variance; $E^{2}=$ permissible error limit $(10 \%) ; N=$ total number of sample units.

The five main species were selected through the characterization of the phytosociological parameters obtained by Alves Júnior et al. (2013) in the same study area, according to Table 1. 
Table 1. Main tree species sampled (no. individuals/ha.) in the phytosociological inventory from the Itapemirim Farm, municipality of Floresta, state of Pernambuco, Brazil.

Tabela 1. Principais espécies arbóreas amostradas ( $n^{\circ}$ indivíduos/ha.) no inventário fitossociológico, realizado na Fazenda Itapemirim, município de Floresta (PE).

\begin{tabular}{lccccccc}
\hline \multicolumn{1}{c}{ Species } & AD & RD & ADo & RDo & AF & RF & IV \\
\hline Poincianella bracteosa (Tul.) L. P. Queiroz & 770 & 47,92 & 3,74 & 46,21 & 100,00 & 11,02 & 105,15 \\
Mimosa ophthalmocentra Mart. ex Benth. & 246,87 & 15,36 & 0,92 & 11,40 & 100,00 & 11,02 & 37,79 \\
Aspidosperma pyrifolium Mart. & 75,62 & 4,71 & 0,47 & 5,78 & 57,50 & 6,34 & 16,82 \\
Myracrodum urundeuva (Engl.) Fr. All. & 51,87 & 3,23 & 0,42 & 5,21 & 65,00 & 7,16 & 15,60 \\
Bauhinia cheilanta (Bong). Steud. & 96,87 & 6,03 & 0,12 & 1,44 & 62,50 & 6,89 & 14,36 \\
\hline Other species (21) & 365,61 & 22,75 & 2,42 & 29,91 & 522,5 & 57,57 & 36,75 \\
\hline Total/ha. & 1606,88 & 100 & 8,09 & 100 & 907,50 & 100 & 300 \\
\hline
\end{tabular}

In which: $\mathrm{AD}=$ Absolute Density; $\mathrm{RD}=$ Relative Density; $\mathrm{ADo}=$ Absolute Dominance; RDo = Relative Dominance; $\mathrm{AF}=\mathrm{Absolute}$ Frequence; RF = Relative Frequence; e IV = Importance Value.

For the diameter structure analysis, a first effort was made through a quantitative survey of the descriptive elements that compose it. Descriptive statistics to obtain preliminary information on the characteristics of this structure were computed. This information was generated from the diameter measured at the base (Db) variable for the stand data and for the five selected species.

The number of diameter classes for the respective cases was defined by the procedure proposed by Sturges (1926):

$$
\begin{gathered}
K=1+3,33 \log N \\
H=d \max -d m i ́ n \\
I C=\frac{K}{H}
\end{gathered}
$$

In which: $K=$ number of classes; $N=$ total number of individuals; $H=$ amplitude between the largest and smallest diameter; $I C=$ interval among classes.

In order to assess the deviation degree, or the distance of the diameter distributions symmetry, the asymmetry moment coefficient was determined, in which: a) asymmetry at right or positive if: mode < median < arithmetic mean; b) asymmetry at left or negative if: mode > median > arithmetic mean; and c) the asymmetry was considered moderate if the asymmetry coefficient, in module, was between 0.15 and 1 , and strong if it was greater than 1 . The asymmetry coefficient was calculated following the methodology recommended by Burkhart and Tomé (2012).

For the analysis of kurtosis, flatness or relative elevation of a distribution, considered usually in relation to the normal distribution, the kurtosis coefficient indicated a curve of the normal type when equal to zero. If the coefficient was positive, the distribution was higher; if negative, a more flat curve was indicated. The kurtosis coefficient was calculated following the methodology recommended by Burkhart and Tomé (2012). It was analyzed as: a) leptokurtic: distribution that has relatively high peak, with negative excess, i.e., kurtosis coefficient $<0.263$; b) platykurtic: curve of flatter top, with positive excess, i.e., kurtosis coefficient > 0.263; and c) mesokurtic: intermediate curve, with kurtosis coefficient $=0.263$.

In order to verify empirically the discrepancies between recruitment and mortality rates by diameter class, both for the stand and for the five species of higher IV, De Liocourt quotient q was used. This analysis was based on the ratio (q) between the number of individuals observed per diameter class and the number of individuals from the following class. We verified that there is a balance or values approximately constant for the q observed values, i.e., for native forests, recruitment would be compensated by mortality (CAMPOS et al., 1983).

The vegetation intrinsic quotient $\mathrm{q}$ was obtained from the adjustment of the statistical model proposed by Meyer (1952):

FLORESTA, Curitiba, PR, v. 48, n. 1, p. 133-142, jan./mar. 2018.

Lima. R.B. et al.

ISSN eletrônico 1982-4688

DOI: $10.5380 /$ rf.v48 i 1.54736 


$$
Y_{i}=\beta_{0} X_{i}^{\beta_{1}}+\varepsilon_{i}
$$

In which: $Y_{i}=$ Frequency per diameter class. In order to make calculus feasible when there were no individuals in any of the classes, the number 1 was added as constant for all classes; $X_{i}=$ diameter class center; $\beta_{0}, \beta_{1}=$ parameters that express the vegetation structure in relation to the diameter distribution; $\varepsilon_{i}=$ random error.

Based on the adjusted distribution function, the vegetation intrinsic quotient $\mathrm{q}$ was obtained through the following equation:

$$
q=\frac{e^{\beta_{0}+\beta_{1} X_{i}}}{e^{\beta_{0}+\beta_{1} X_{i+1}}}
$$

In which: it is used the ratio between the frequencies of any diameter class $\left(\mathrm{X}_{\mathrm{i}}\right)$ by the frequency of the immediately larger diameter class $\left(\mathrm{X}_{\mathrm{i}+1}\right)$.

The statistical model parameters were obtained by maximum likelihood, by using the Software R MASS package (R Core Team, 2015).

\section{RESULTS}

Sampling sufficiency results indicated that there was stability of the collector curve regarding number of species (24) between the 13th and 35th plots, ie, from $5.200 \mathrm{~m}^{2}$ on, the sampling was representative (Figure 1), properly simulating the composition of inventoried species in the community studied. It was also observed that there was a large sampling effort for the appearance of two more species from the 37 th plot on, that is, an increase of $284.61 \%$ regarding the sampled area.

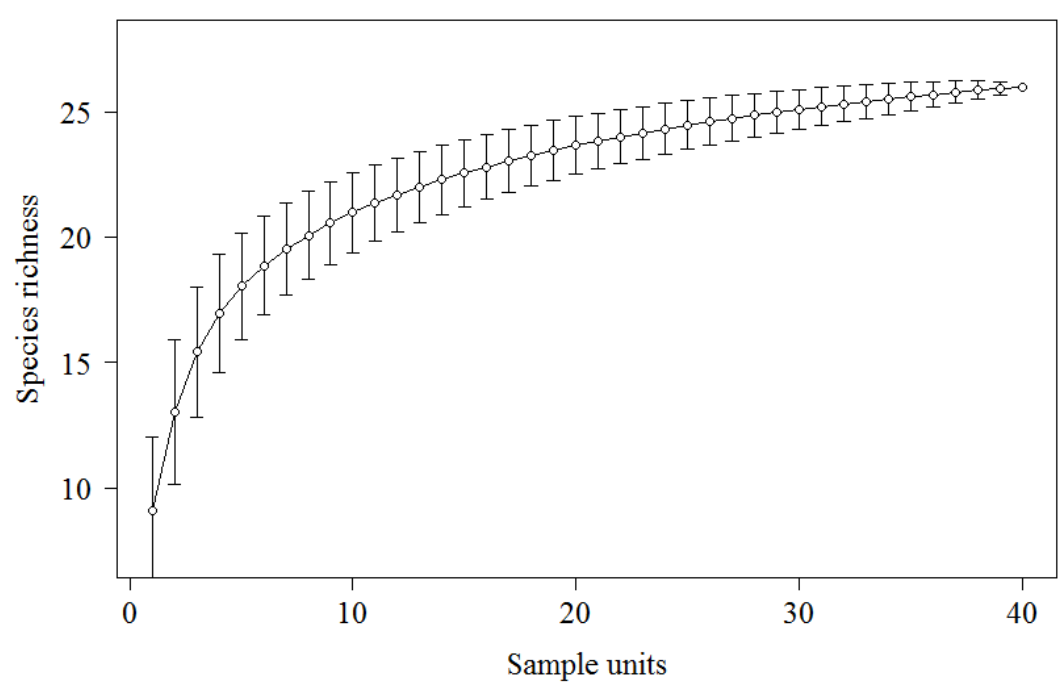

Figure 1. Sampling sufficiency, "Area x Number of sampled species", Itapemirim Farm, municipality of Floresta (PE). The vertical bars indicate the standard deviation of the number of individuals for each species in all the inventoried plots.

Figura 1. Suficiência amostral, "Área x Número de espécies amostradas", Fazenda Itapemirim, município de Floresta (PE). As barras na vertical indicam o desvio padrão do número de indivíduos para cada espécie em todas as parcelas inventariadas.

Table 2 shows the descriptive statistics for base diameter ( $\mathrm{Db}$ in $\mathrm{cm}$ ), both for the stand and for higher IV species. The largest $\mathrm{Db}$ found in the area was $40.7 \mathrm{~cm}$ and the smallest was $1.9 \mathrm{~cm}$. It was noted that Poincianella bracteosa (catingueira) concentrated approximately $47.9 \%$ of the individuals sampled, with an average similar to that found in the stand. It was also possible to verify that Mimosa ophthalmocentra (jurema-de-embira), second highest in the IV ranking, presented the lowest relative dispersion around the mean in relation to the diameter. 
Table 2. Descriptive statistics for the base diameter for the stands and species of higher IV found in the Itapemirim Farm, municipality of Floresta, state of Pernambuco, Brazil.

Tabela 2. Estatísticas descritivas para o diâmetro da base para o povoamento e para as espécies de maior VI, encontrados na Fazenda Itapemirim, município de Floresta(PE).

\begin{tabular}{|c|c|c|c|c|c|c|}
\hline \multirow[b]{2}{*}{ Measure } & \multirow[t]{2}{*}{ Stand } & \multicolumn{5}{|c|}{ Species } \\
\hline & & $\begin{array}{c}\text { Poincianella } \\
\text { bracteosa }\end{array}$ & $\begin{array}{c}\text { Mimosa } \\
\text { ophthalmocentra }\end{array}$ & $\begin{array}{c}\text { Myracrodum } \\
\text { urundeuva }\end{array}$ & $\begin{array}{c}\text { Aspidosperma } \\
\text { pyrifolium }\end{array}$ & $\begin{array}{l}\text { Bauhinia } \\
\text { cheilanta }\end{array}$ \\
\hline $\mathrm{N}^{\mathrm{o}}$ individuals & 2.571 & 1232 & 395 & 83 & 121 & 155 \\
\hline Mean $(\mathrm{cm})$ & 6,7 & 6,8 & 6,3 & 8,4 & 7,8 & 3,3 \\
\hline Median (cm) & 5,4 & 5,7 & 5,7 & 5,7 & 6,6 & 2,9 \\
\hline Mode $(\mathrm{cm})$ & 3,2 & 3,8 & 5,1 & 3,2 & 6,4 & 2,5 \\
\hline $\operatorname{Dbmin}(\mathrm{cm})$ & 1,9 & 1,9 & 2,2 & 2,2 & 2,2 & 1,9 \\
\hline $\operatorname{Dbmax}(\mathrm{cm})$ & 40,7 & 28,6 & 25,1 & 22,6 & 24,8 & 24,2 \\
\hline Range $(\mathrm{cm})$ & 38,8 & 26,7 & 22,9 & 20,4 & 22,6 & 22,3 \\
\hline $\begin{array}{l}\text { Variance } \\
\left(\mathrm{cm}^{2}\right)\end{array}$ & 19,8 & 15,4 & 7,7 & 33,2 & 18,7 & 4,4 \\
\hline $\begin{array}{l}\text { Standard dev. } \\
(\mathrm{cm})\end{array}$ & 4,5 & 3,9 & 2,8 & 5,8 & 4,3 & 2,1 \\
\hline $\mathrm{CV} \%$ & 66,8 & 57,7 & 43,8 & 68,5 & 55,7 & 63,4 \\
\hline Asymmetry & 2,6 & 2,2 & 2,1 & 0,7 & 1,6 & 7,7 \\
\hline Kurtosis & 9,9 & 7,0 & 8,4 & $-0,7$ & 2,9 & 70,1 \\
\hline
\end{tabular}

In which: Dbmin $(\mathrm{cm})=$ smallest base diameter; Dbmax $(\mathrm{cm})=$ largest base diameter; CV\% = Coefficient de Variation.

The values of the asymmetry, mode, median and mean coefficients, both for the stand and for the species of higher IV, showed that the diametric distributions were positive asymmetric, with a higher concentration of the diameter on the left side of the distribution. Therefore, it is understood that the tails of the curves extended to the right side, where the mean value is higher than the mode and median values.

Based on the values of the kurtosis coefficients, it was possible to infer that the majority of the distributions were platykurtic, that is, the curves were flatter than the normal curve, with positive excess and with a higher standard deviation from the evaluated diameters. The Myracrodum urundeuva species was the exception, with a negative kurtosis coefficient (less than 0.263), indicating a leptokurtic distribution according to Machado et al. (2009a).

Through an assessment of the number of individuals per diameter class (Figure 2), it was possible to observe that, for the forest fragment, Myracrodum urundeuva and Bauhinia cheilanta, 42.5, 37 and $95.4 \%$ of the individuals were concentrated in the initial diameter classes, ranging from 1.9 to $4.9 \mathrm{~cm} ; 2.2$ to $5.2 \mathrm{~cm}$ and 1.9 to $4.9 \mathrm{~cm}$ respectively. For Poincianella bracteosa, the highest concentration occurred among the initial classes (72.64\%), which include diameters between 1.9 and $7.9 \mathrm{~cm}$.

It was also noted that $81.51 \%$ of Mimosa ophthalmocentra individuals had diameters ranging from 2.2 to $8.2 \mathrm{~cm}$, and $68.59 \%$ of the individuals of Aspidosperma pyrifolium occupied the initial diameter classes, varying from 2.2 to $8.2 \mathrm{~cm}$. These results suggest that the Caatinga vegetation studied was occupied by individuals of small sizes, concentrating a great density of trees in the initial diameter classes. This fact was previously verified in the descriptive statistics for the base diameter values, presenting a positive asymmetric diametric structure.

FLORESTA, Curitiba, PR, v. 48, n. 1, p. 133-142, jan./mar. 2018.

Lima. R.B. et al.

ISSN eletrônico 1982-4688

DOI: $10.5380 /$ rf.v48 i1.54736 

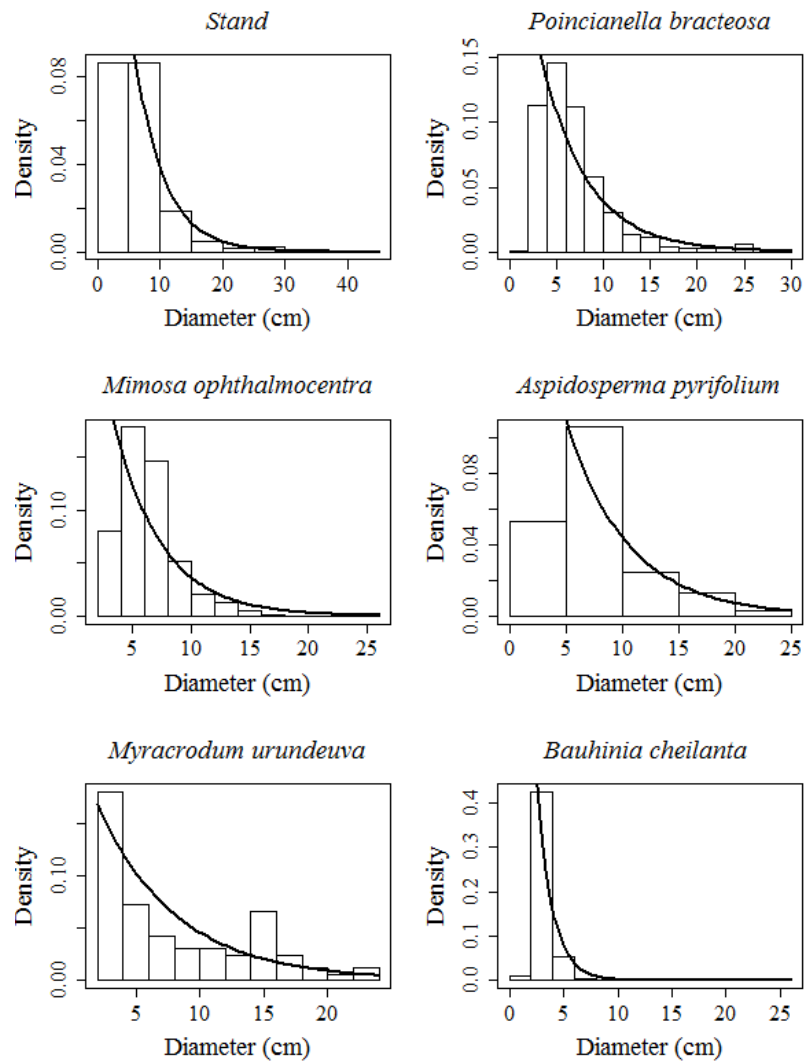

Figure 2. Diametric distribution histograms for the fragment and for the highest IV species, sampled at the Itapemirim Farm, in the municipality of Floresta (PE).

Figura 2. Histogramas de distribuição diamétrica para o fragmento e para as espécies de maior VI, amostrados na Fazenda Itapemirim, município de Floresta(PE).

The values observed for the Liocourt quotient $\mathrm{q}$ showed different trends between recruitment and mortality in the diametric structure, both for the fragment and for the species of higher IV studied. A deficit of individuals was noted for the fragment and for the Poincianella bracteosa, Mimosa ophthalmocentra and Bauhinia cheilanta species, mainly in classes with diameters larger than $20 \mathrm{~cm}$. The different composition of individuals in the defined classes suggests an ample variation between the values found for quotient $\mathrm{q}$, as in the Bauhinia cheilanta species (Table 3).

Table 3. Results of the Meyer model fit for the stand and species of higher IV, Itapemirim Farm, municipality of Floresta, state of Pernambuco, Brazil.

Tabela 3. Resultados do ajuste do modelo de Meyer para o fragmento e para as espécies de maior VI, Fazenda Itapemirim,município de Floresta (PE).

\begin{tabular}{|c|c|c|c|c|c|c|}
\hline \multirow{2}{*}{ Fit } & \multicolumn{2}{|c|}{ Coefficients } & \multirow{2}{*}{$\mathbf{R}^{2}$} & \multicolumn{2}{|c|}{ Quotient q } & \multirow{2}{*}{ Standard error } \\
\hline & $\mathbf{b}_{0}$ & $\mathbf{b}_{1}$ & & Observed* & Estimated & \\
\hline Stand & 0,2106 & 1,9099 & 0,94 & 1,9026 & 1,760 & 0,8668 \\
\hline Poincianella bracteosa & 0,2040 & 1,9099 & 0,87 & 1,4733 & 1,536 & 0,5992 \\
\hline Mimosa ophthalmocentra & 0,2444 & 2,2282 & 0,88 & 1,9966 & 1,803 & 1,6478 \\
\hline Aspidosperma pyrifolium & 0,1807 & 2,2282 & 0,95 & 1,9235 & 1,802 & 1,1232 \\
\hline Myracrodum urundeuva & 0,1618 & 2,2282 & 0,71 & 1,398 & 1,376 & 0,4681 \\
\hline Bauhinia cheilanta & 0,7124 & 1,9099 & 0,52 & 5,5071 & 1,632 & 10,6547 \\
\hline
\end{tabular}

(*) Values obtained by the arithmetic mean of the quoticients $\mathrm{q}$ of the diameter classes. $\mathrm{R}^{2}=$ Coefficient of determination.

The fitting of the frequency distributions by diameter class for the six analyzed cases reported a good use of the Meyer model (Figure 2), fitting well to a negative exponential regression, with acceptable limits of total 
explained variances of $71 \%$ for Myracrodum urundeuva to $95 \%$ for Aspidosperma pyrifolium. The worst fitting was for Bauhinia cheilanta $\left(\mathrm{R}^{2}=52 \%\right)$.

\section{DISCUSSION}

According to Alves et al. (2013) and Péllico Neto and Brena (1997), it is essential to carry out the analysis of sampling sufficiency in phytosociological research, since the cumulative additional species curve, in the actual order of the plots, allows the assessment of the survey's sampling effort. The number of established sample units required can be infered, whether or not beingsuitable for knowledge about the population.

According to Schilling et al. (2012) in papers regarding the structure of tropical forests, or regarding the curves generated in the order in which the plots were measured in the field and considered as the "natural" order to determine the number of species, or yet regarding the number of plots or sampled area, it is common for the researcher to interpret rapid growth or temporary levels as characteristic attributes of the community being studied.

In Petrolina (PE), Calixto Júnior and Drummond (2011) also found the highest concentration of individuals in the first three classes in an area consisting mainly of Caatinga. Thus, the distribution can be considered typical of native forests and is similar to the model in the form of an "inverted J", or negative or decreasing exponential distribution. According to Machado et al.(2009b), this behavior in the diametric structure of native forests indicates that regeneration occurs continuously.

For the decreasing distributions, the increase in the concentration or probability of individuals around the classes of smaller diameter results in higher kurtosis, that is, the curves generated tend to present a higher top in relation to the standard normal curve. This happens even though the distribution of individuals of the same species - in the form of a histogram with higher or lower top - is an attempt to analyze their developmental stages, in which the proportions of the members of a population belonging to each class are indicated (MARTÍNEZANTÚNEZ et al., 2015). Although kurtosis is often explained as a "flatness" in function of the variance of frequency distribution diameters, this parameter actually indicates the degree of value concentration of the distribution around the center of the same distribution (ROBINSON; HAMANN, 2011; BURKHART; TOMÉ, 2012). Graphically, this peculiarity is associated to curves with longer tails for the classes of intermediate diameter, with a frequency peak more pronounced in the initial classes. In dry tropical forests, these characteristics of diameters distribution described by asymmetry and kurtosis can be influenced by the forest dynamics. The precipitation indexes cause structural and ecological changes in the tree growth and affect the distribution, usually decreasing the values of asymmetry and kurtosis (NATH et al., 2006, HILTNER et al., 2015).

Considering the whole fragment, it is possible to identify a low density of individuals in the upper classes with diameters longer than $30 \mathrm{~cm}(0.35 \%)$. For species with higher IV, relatively low tree densities $(3.61 \%$ for Myracrodum urundeuva; $1.94 \%$ for Poincianella bracteosa; $0.5 \%$ for Mimosa ophthalmocentra; $0.64 \%$ for Bauhinia cheilanta; and $1.65 \%$ for Aspidosperma pyrifolium) reach diameters greater than $20 \mathrm{~cm}$. According to Dantas et al. (2010), this shows that the secondary succession stage predominates in the vegetation, which is corroborated by the greater number of individuals sampled in the first classes.

The highest concentration of individuals in the first diameter classes for the stand is largely due to the Poincianella bracteosa species, for its wide density and dispersion and for its status of dominant species in different successional stages of the Caatinga (SANTANA et al., 2011). These data of the species strengthen the idea of Sampaio et al. (1998), who claims to be possible for Poincianella bracteosa, in the process of succession, to adopt the strategies of small but strong relative initial growth, drought resistance and good competition for light, as well as the ability to regrow by stumps and roots.

Figueirôa et al. (2008) stated that, in case of shallow cut, the species Poincianella bracteosa survives independently of the climatic season in a time interval longer than one year. However, Santana et al. (2011) stated that, under normal conditions of dry forest with xerophilous characteristics, several young individuals do not complete their cycle due to natural succession processes. The reduction of individuals in classes of diameter smaller than $15 \mathrm{~cm}$ can lead to an exponential decrease in species level, as well as alter the dynamics of the plant populations, compromising the natural regeneration process and, therefore, the sustainability of the systems. Although the Caatinga vegetation studied does not indicate a history of deforestation, it is necessary that a significant number of individuals belonging to the classes of smaller size exist in order for the survival of these communities to be guaranteed.

Balanced diameter distributions, in which recruitment compensates for mortality over time, exhibit relatively constant values for the constant "q" among the diameter classes (MEYER, 1952). According to Alves Júnior et al. (2013), since the value of the constant "q" is influenced by the frequencies of all diameter classes and not only by those of the lower value classes, low frequencies in the larger classes or the absence of individuals of certain classes can explain the variation of the values of "q" found. Thus, this can influence the concept of balanced

FLORESTA, Curitiba, PR, v. 48, n. 1, p. 133-142, jan./mar. 2018.

Lima. R.B. et al.

ISSN eletrônico 1982-4688

DOI: $10.5380 /$ rf.v48 i1.54736 
forest, in which the mortality of individuals of a given diameter class is compensated by the recruitment of classes with greater density.

In this context, it is also worth noting that the study area did not show any signs of exploitation, and that the diameter structure of the fragment, of Poincianella bracteosa and of Myracrodum urundeuva tended to show balance between recruitment and mortality. Nascimento et al.(2004), while studying both the shrub-tree community and species of higher IV, also found different tendencies in the values of the quotient "q". However, these authors affirmed that Myracrodum urundeuva presented deficit or discontinuity of individuals within the classes, due to the extraction of wood for producing firewood.

The values of the constant "q" estimated from the equation ranged from a minimum of 1.376 (Myracrodum urundeuva) to 1.803 (Mimosa ophthalmocentra). This indicates that the use of the Meyer equation for different databases, originating different curve tendencies, can later facilitate the determination of cutting intensity by diameter class at community level or species level, such as silviculture treatment (CAMPOS et al., 1983) or the production of wood for energy according to the management plans in the region.

It is worth noting that the diameter distribution pattern, both for the community as for the higher IV species, in which the largest representation of individuals occurs in the first diameter classes and decreases exponentially in the following classes, may indicate a short life cycle with size limited by genetic characteristics (SANTANA et al., 2011), short regeneration time in the forest (the forest is at the beginning of the regeneration process), or limited potential for growth in the area, not reaching higher diameter grades.

\section{CONCLUSIONS}

- The diameter distribution for the fragment and for the species of higher IV presented a typical pattern of distribution regarding native forests, with a higher concentration of individuals in the initial diameter classes, configured as a curve of the decreasing exponential type.

- The "q" values obtained indicated that recruitment may be compensating the natural mortality for the individuals of Poincianella bracteosa, Aspidosperma pyrifolium and Myracrodum urundeuva. The diameter structures of the fragment and of the other species suggest discontinuity or deficit of individuals, especially in classes located in the distribution tails, affecting the dynamics, recruitment and maintenance of the analyzed communities.

\section{REFERENCES}

AIDE, T. M.; CLARK, M. L.; GRAU, H. R.; LÓPEZ-CARR, D.; LEVY, M. A.; REDO, D.; BONILLAMOHENO, M.; RINER, G.; ANDRADE-NÚÑEZ, M. J.; MUÑIZ, M. Deforestation and reforestation of Latin America and the Caribbean (2001-2010). Biotropica, Washington, v. 45, n. 2, p. 262-271, 2012.

ALVES, A. R.; RIBEIRO, I. B.; SOUSA, J. R. L.; BARROS, S. S.; PERIVELTON DA SILVA SOUSA, P. S. Análise da estrutura vegetacional em uma área de caatinga no Município de Bom Jesus, Piauí. Revista Caatinga, Mossoró, v. 26, n. 4, p. 99-106, 2013.

ALVES JUNIOR F. T.; FERREIRA R. L. C.; SILVA J. A. A.; MARANGON L. C.; CESPEDES G. H. G. Structure evaluation of the Caatinga vegetation for sustainable forest management in the municipality of Floresta, Pernambuco, Brazil. In: GUNKEL, G.; SILVA, J. A. A.; SOBRAL, M. C. Sustainable Management of Water and Land in Semiarid Areas. Recife: Ed. UFPE. 2013, 280 p.

BURKHART, H. E.; TOMÉ, M. Modeling Forest Trees and Stands. Dordrecht Heidelberg, New York, London, United Kingdown: Springer. 2012, 461 p.

CALIXTO JÚNIOR, J. T.; DRUMMOND, M. A. Estrutura fitossociológica de um fragmento de Caatinga sensustricto 30 anos após corte raso, Petrolina-PE, Brasil. Revista Caatinga, Mossoró, v. 24, n. 2, p. 67-74, 2011.

CAMPOS, J. C. C.; RIBEIRO, J. C.; COUTO, L.. Emprego da distribuição diamétrica na determinação da intensidade de corte em matas naturais submetidas ao sistema de seleção. RevistaÁrvore, Viçosa, v.7, n.2, p.110$122,1983$.

COMITÊ TÉCNICO CIENTÍFICO DA REDE DE MANEJO FLORESTAL DA CAATINGA. Protocolo de medições de parcelas permanentes. Recife: Associação Plantas do Nordeste. 2005, 30 p. 
DANTAS, J. G.; HOLANDA; A. C., SOUTO, L. S.; JAPIASSU, A.; HOLANDA, E. M. Estrutura do componente arbustivo/arbóreo de uma área de Caatinga situada no município de Pombal-PB. Revista Verde, Mossoró, v.5, n.1, p. 134-142, 2010.

EMBRAPA - Empresa Brasileira de Pesquisa Agropecuária. Diagnóstico Ambiental do Município de Floresta, Pernambuco. Circular Técnica n ${ }^{\circ}$ 10. Rio de Janeiro, RJ. Dezembro. 2001, 10 p.

EMBRAPA - Empresa Brasileira de Pesquisa Agropecuária. Sistema brasileiro de classificação de solos. 2. ed. - Rio de Janeiro: EMBRAPA-SPI. 2006, 306 p.

FIGUEIRÔA, J. M. D.; ARAÚJO, E. D. L.; PAREYN, F. G. C.; CUTLER, D. F.; GASSON, P.; LIMA, K. C.; SANTOS, V. F. D. Variações sazonais na sobrevivência e produção de biomassa de Caesalpinia pyramidalis Tul. após corte raso e implicações para o manejo da espécie. Revista Árvore, Viçosa, v.32, n.6, p.1041-1049, 2008.

HILTNER, U.; BRAUNING, A.; GEBREKIRSTOS, A.; HUTH, A.; FISCHER, R. Impacts of precipitation variability on the dynamics of a dry tropical montane forest. Ecological Modelling, Amsterdam, v. 320, p. 92$101,2015$.

INSTITUTO BRASILEIRO DE GEOGRAFIA E ESTATÍSTICA - IBGE. Manual Técnico da Vegetação Brasileira. $2^{\mathrm{a}}$ Ed. Rio de Janeiro, 2012, 271 p.

MACHADO, S. D. A.; AUGUSTYNCZIK, A. L. D.; NASCIMENTO, R. G. M.; FIGURA, M. A.; SILVA, L. C. R. D.; MIGUEL, E. P.; TÉO, S. J. Distribuição diamétrica de Araucaria angustifólia (Bert.) O. Ktze. Em um fragmento de floresta ombrófila mista. Scientia Agraria, Curitiba, v.10, n.2, p. 103-110, 2009a.

MACHADO, S. A.; AUGUSTYNCZIK, A. L. D.; NASCIMENTO, R. G. M.; TÉO, S. J.; MIGUEL, E. P.; FIGURA, M. A.; SILVA, L. C. R. Funções de distribuição diamétrica em um fragmento de Floresta Ombrófila Mista. Ciência Rural, Santa Maria, v.39, n.8, p.2428-2434, 2009 b.

MARTÍNEZ-ANTÚNEZ, P.; WEHENKEL, C.; HERNÁNDEZ-DÍAZ, J. C.; CORRAL-RIVAS, J. J. Use of the Weibull function to model maximum probability of abundance of tree species in northwest Mexico. Annals of Forest Science, Les Ulis, v.72: 243-251, 2015.

MEYER, H. A. Structure, growth, and drain in balanced uneven-aged forests. Journal of Forestry, Maryland, v. 50, n. 2, p. 85-92, 1952.

NASCIMENTO, A. R. T.; FELFILI, J. M.; MEIRELLES, E. M. Florística e estrutura da Povoamento de um remanescente de Floresta Estacional Decidual de encosta, Monte Alegre, GO, Brasil. Acta Botânica Brasílica, Belo Horizonte, v.18, n.3, p. 659-669, 2004.

NATH, C. D.; DATTARAJA, H. S.; SURESH, H. S.; JOSHI, N. V.; SUKUMAR, R.Patterns of tree growth in relation to environmental variability in the tropical dry deciduous forest at Mudumalai, southern India. Journal of Biosciences v. 31, p. 651-669, 2006.

PORTILlO-QUINTERO, C.; SÁNCHEZ-AZOFEIFA, G. A. Extent and conservation of tropical dry forests in the Americas. Biological Conservation, Essex, v. 143, p. 144-155, 2010.

PÉLLICO NETTO, S.; BRENA, D.A. Inventário Florestal. Curitiba: UFPR, 1997. v.1, 316p.

POWERS, J.S.; BECKNELL, J.M.; IRVING,J.; PÈREZ-AVILES, D. Diversity and structure of regenerating tropical dry forests in Costa Rica: Geographic patterns and environmental drivers. Forest Ecology and Management, Amsterdam, v.258, p. 959-970, 2009.

ROBINSON, A. P.; HAMANN, J. D. Forest Analytics with R: An Introduction. Springer, New York Dordrecht Heidelberg, London, United Kingdown. 2011, 339 p.

RUBIN, B. D.; MANION, P. D.; FABER-LANGENDOEN, D. Diameter distributions and structural sustainability in forests.Forest Ecology and Management, Amsterdam, v.222, p. 427-438, 2006.

SAMPAIO, E. V. D. S. B.; ARAÚJO, E. L.; SALCEDO, I. H.; TIESSEN, H. Regeneração da vegetação de Caatinga após corte e queima, em Serra Talhada, PE. Pesquisa Agropecuária Brasileira, Brasília, v. 33, n. 5, p. $621-632,1998$.

FLORESTA, Curitiba, PR, v. 48, n. 1, p. 133-142, jan./mar. 2018.

Lima. R.B. et al.

ISSN eletrônico 1982-4688

DOI: $10.5380 /$ rf.v48 i1.54736 
SANTANA, J. A. S.; VIEIRA, F. A.; PACHECO, M. V.; OLIVEIRA, P. R. S. Padrão de distribuição e estrutura diamétrica de Caesalpinia pyramidalis Tul. (Poincianella bracteosa) na Caatinga do Seridó. Revista de Biologia e Ciências da Terra, Campina Grande, v.11, n. 1, p. 116-122, 2011.

SCHILlinG, A. C.; BATISTA, J. L. F.; COUTO, H. Z. Ausência de estabilização da curva de acumulação de espécies em florestas tropicais. Ciência Florestal, Santa Maria, v. 22, n. 1, p. 101-111, 2012.

STURGES, H. The choice of a class-interval. Journal American Statistical Association, Nova York, v. 21, p. 65-66, 1926. 